\title{
Ecotoxicity and Hemolytic Activity of Fluorinated Ionic Liquids
}

\author{
Nicole S. M. Vieira ${ }^{1}\left(\mathbb{D}\right.$, Ana L. S. Oliveira ${ }^{1}$, João M. M. Araújo ${ }^{1} \mathbb{D}$, Maria Manuela Gaspar ${ }^{2} \mathbb{D}$ \\ and Ana B. Pereiro $1, *$ (D)
}

1 LAQV, REQUIMTE, Departamento de Química, Faculdade de Ciências e Tecnologia, Universidade Nova de Lisboa, 2829-516 Caparica, Portugal; ns.vieira@campus.fct.unl.pt (N.S.M.V.); als.oliveira@campus.fct.unl.pt (A.L.S.O.); jmmda@fct.unl.pt (J.M.M.A.)

2 Research Institute for Medicines (iMed.ULisboa), Faculty of Pharmacy, Universidade de Lisboa, Av. Prof. Gama Pinto, 1649-003 Lisboa, Portugal; mgaspar@ff.ulisboa.pt

* Correspondence: anab@fct.unl.pt; Tel.: +351-212948318

Citation: Vieira, N.S.M.; Oliveira, A.L.S.; Araújo, J.M.M.; Gaspar, M.M.; Pereiro, A.B. Ecotoxicity and Hemolytic Activity of Fluorinated Ionic Liquids. Sustain. Chem. 2021, 2, 115-126. https://doi.org/10.3390/ suschem 2010008

Received: 28 January 2021

Accepted: 23 February 2021

Published: 2 March 2021

Publisher's Note: MDPI stays neutral with regard to jurisdictional claims in published maps and institutional affiliations.

Copyright: (C) 2021 by the authors Licensee MDPI, Basel, Switzerland. This article is an open access article distributed under the terms and conditions of the Creative Commons Attribution (CC BY) license (https:// creativecommons.org/licenses/by/ $4.0 /)$.

\begin{abstract}
The task-specific design of ionic liquids (ILs) has emerged in several industrial and pharmaceutical applications. The family of ILs with fluorine tags equal to or longer than four carbon atoms, the fluorinated ionic liquids (FILs), combine the best properties of ILs with the ones of perfluorinated compounds, and are being designed for several specific purposes. In the pharmaceutical field, there is an urgency to search for novel antibacterial agents to overcome problems associated to antimicrobial resistances. Then, the main purpose of this work is to evaluate the environmental impact and the ability of FILs to be used as antibacterial agents against Pseudomonas stutzeri bacteria. Beyond its rare pathogenicity, these bacteria are also used as a bioremediation agent to treat several contamination sites. Then, it is important to determine which FILs have antibacterial properties, and which do not impact the bacterial growth. The biocompatibility of FILs was also evaluated through their hemolytic activity and represent a step forward the application of FILs in pharmaceutical applications. The results proved that high concentrations of FILs can have a reduced ecotoxicity and a high biocompatibility. $\left[\mathrm{C}_{8} \mathrm{C}_{1} \mathrm{Im}\right]\left[\mathrm{CF}_{3} \mathrm{SO}_{3}\right]$ was identified as the most promising compound to be used as an antibacterial agent since it prevents the growth of bacteria at concentrations compatible with the red blood cells' viability.
\end{abstract}

Keywords: fluorinated ionic liquids; Pseudomonas stutzeri; antibacterial properties; hemolytic activity

\section{Introduction}

The task-specific design of materials and the improvement of industrial processes through sustainable and greener ionic liquids (ILs) have emerged in the last decades in many fields of interest, such as catalysis [1-3], energy and electrochemistry [4], lubricants [5], the design of new materials for gas absorption [6], separation and extraction processes [7-9], the design of stimuli-responsive materials and sensors [10,11], and biomedical and pharmaceutical applications [12-17]. The application of ILs in such broad range of fields are supported by their great tuneability, since their final properties are dependent on the cation-anion selected pair. Amongst the most advantageous properties of ILs are their high thermal stability and "green nature", endorsed by their low flammability and reduced vapor pressure [18-21], as well as by their biocompatibility and reduced environmental toxicity associated to several cation-anion combinations [22,23].

The use of ILs in the pharmaceutical field have covered topics such as the screening for antifungal, antiviral, antioxidant and anticancer properties (such as the capacity to inhibit tumor progression), the design of new pharmaceutics and drug delivery systems, as well as the improvement of several analytical techniques and drug synthesis processes [12-17]. Furthermore, the urgent need to evaluate the antibacterial properties of ILs has also been noticed, in order to screen for new substances with potential pharmacological value that may represent a better alternative to traditional treatment and an advantage regarding 
the constant increment of antimicrobial resistances that hampers the treatment of several infections. The ability to inhibit the growth of several pathogens has been detected for several common imidazolium, pyridinium, ammonium, piperidinium and pyrrolidiniumbased ILs, among others [22,24-30]. Moreover, it is well known that the increment of the alkyl side chain length plays a major role in the antimicrobial potency of ILs, which can be related to a mechanism of cell membrane disruption boosted by the higher hydrophobicity associated with longer alkyl chains-based compounds [27-30]. However, the introduction of hydroxyethyl groups in the IL side chain causes a reduction of the antimicrobial activity $[30,31]$. Although the anion effect has been generally less studied in comparison to the cation core [24], the selection of metal-based anions has been proved to significantly impact the microbial viabilities, which can be linked to the capacity of these compounds to produce reactive oxygen species and protein denaturation, which can destabilize several cellular pathways [32]. ILs have demonstrated their clinical value as antimicrobial agents through the ability to form antibacterial films towards a broad range of pathogens, to enhance the antibacterial activity of several antibiotics when synthesized in an IL-based platform, such as an ampicillin-based IL, and to avoid the development of biofilms of multidrug-resistant species [33,34]. Moreover, due to these antimicrobial properties, ILs can also be used in industry as protective agents to preserve several materials and cultural heritage $[14,23]$. During these screening processes, a proper balance between the antimicrobial activity and the hemocompatibility and cytotoxicity of the compounds must occur. Moreover, the screening and selection approaches must be carried out with some caution and must always consider the final objective. For biomedical approaches, the growth inhibition of microbial species is desirable. However, when considering bioremediation and biotechnological processes such as biocatalysis and biotransformation, involved in ethanol production, dairy industry, and biosorption of uranium, this growth inhibition causes a loss in the effectiveness of the process [35-38]. Then, when the main goal is to select ILs to be used in biotechnological processes, their impact on microbial or enzymatic species must be reduced.

Within the ILs category, there is a specific family of compounds-the fluorinated ionic liquids (FILs) - characterized by having fluorinated tags equal to or longer than four carbon atoms $[39,40]$ that combine the best properties of ILs with the outstanding properties of conventional perfluorocarbons, such as high surfactant behavior, low surface tension and chemical and biological inertness [41,42]. These compounds have three nanosegregated domains (polar, nonpolar, and fluorinated) enabling the formation of unique structures and the solubilization of different types of compounds [40,43-45]. Few studies were conducted by our group reporting the negligible cytotoxicity of FILs with short hydrogenated and fluorinated side chains in four different human cell lines (Caco-2, HepG2, Ea.hy926 and HaCa-T) [39,46]. Additionally, no acute ecotoxicity was detected for different perfluorobutanesulfonate and perfluoropentanoate-based FILs towards different aquatic microorganisms with different hierarchical orders, such as bacteria (Vibrio fischeri), crustaceans (Daphnia magna) and an aquatic plant (Lemna minor) [31]. These results support the application of FILs for either industrial processes or pharmaceutical applications, as well as for their use as a sustainable alternative for traditional perfluorocarbons displaying low solubility and high toxicity. These properties have endorsed their application in pharmaceutical development, in which they have been tested as delivery and stabilizing agents for two different biomolecules, lysozyme and bovine serum albumin (BSA), without inducing protein conformational changes [47-49]. Imidazolium and pyridinium-based FILs have demonstrated the ability to encapsulate lysozyme with relatively high efficiencies, without affecting the biological activity of the biomolecule $[47,48]$. Besides, both imidazolium and choline-based FILs were proved to stabilize BSA, and interaction studies between the aromatic FIL and the biomolecule evidenced the encapsulation of BSA, as well as the maintenance of the FIL-protein interaction [49].

The main goal of this study is to evaluate the antimicrobial activity of several FILs, as well as their environmental safety, against the denitrifying Pseudomonas stutzeri (P. stutzeri) 
bacteria. This Gram-negative bacterium is widely distributed in the environment and intensively used for environmental studies [50-53]. P. stutzeri is also considered a bioremediation agent for several contaminants in a cost-effective and environmentally friendly approach $[52,53]$. Its ability to remove metal working fluids, pesticides and polycyclic aromatic hydrocarbons has already been addressed, as well as the removal of dyes after a process of acclimation using ionic liquids [35]. Additionally, these bacteria were also used to produce and isolate new biocorrosion and antibacterial agents [54,55]. Unfortunately, P. stutzeri were isolated from hospital environments, and associated with patients suffering from human immunodeficiency virus disease being considered a rare, but opportunistic pathogen [50]. To the best of our knowledge, the research dealing with P. stutzeri and ionic liquids was mostly focused on the improvement of bioremediation technologies [35]. This work will be focused on the screening for FIL-based antibacterial compounds, supported by the bacterial growth and hemocompatibility assays. The bacterial growth assays will be also used to select ecofriendly FILs that can be applied in industrial processes or released in the environment without prejudice for the growth of these bacteria present in several bioremediation processes.

\section{Materials and Methods}

\subsection{Materials}

The fluorinated ionic liquids used in this work were: 1-ethyl-3-methylimidazolium perfluoromethanesulfonate $\left(\left[\mathrm{C}_{2} \mathrm{C}_{1} \mathrm{Im}\right]\left[\mathrm{CF}_{3} \mathrm{SO}_{3}\right],>99 \%\right.$ mass fraction purity), 1-methyl-3octylimidazolium perfluoromethanesulfonate $\left(\left[\mathrm{C}_{8} \mathrm{C}_{1} \mathrm{Im}\right]\left[\mathrm{CF}_{3} \mathrm{SO}_{3}\right],>99 \%\right.$ mass fraction purity), 1-ethyl-3-methylimidazolium perfluorobutanesulfonate $\left(\left[\mathrm{C}_{2} \mathrm{C}_{1} \mathrm{Im}\right]\left[\mathrm{C}_{4} \mathrm{~F}_{9} \mathrm{SO}_{3}\right],>97 \%\right.$ mass fraction purity), 1-mehtyl-3-octylimidazolium perfluorobutanesulfonate $\left(\left[\mathrm{C}_{8} \mathrm{C}_{1} \mathrm{Im}\right]\left[\mathrm{C}_{4} \mathrm{~F}_{9} \mathrm{SO}_{3}\right]\right.$, $>98 \%$ mass fraction purity), 1-ethyl-3-methylpyridinium perfluorobutanesulfonate $\left(\left[\mathrm{C}_{2} \mathrm{C}_{1}\right.\right.$ py] $\left[\mathrm{C}_{4} \mathrm{~F}_{9} \mathrm{SO}_{3}\right], \geq 99 \%$ mass fraction purity) and choline ((2-hydroxyethyl)trimethylammonium) perfluorobutanesulfonate, $\left(\left[\mathrm{N}_{1112(\mathrm{OH})}\right]\left[\mathrm{C}_{4} \mathrm{~F}_{9} \mathrm{SO}_{3}\right], \geq 97 \%\right.$ mass fraction purity). These ILs were supplied by IoLiTec $\mathrm{GmbH}$ (Salzstraße, Heilbronn, Germany). On the other hand, 1-ethyl-3methylimidazolium perfluoropentanoate $\left(\left[\mathrm{C}_{2} \mathrm{C}_{1} \mathrm{Im}\right]\left[\mathrm{C}_{4} \mathrm{~F}_{9} \mathrm{CO}_{2}\right],>99 \%\right.$ mass fraction purity), 1-ethyl-3-methylpyridinium perfluoropentanoate $\left(\left[\mathrm{C}_{2} \mathrm{C}_{1}\right.\right.$ py $]\left[\mathrm{C}_{4} \mathrm{~F}_{9} \mathrm{CO}_{2}\right],>99 \%$ mass fraction purity), and choline perfluoropentanoate $\left(\left[\mathrm{N}_{1112(\mathrm{OH})}\right]\left[\mathrm{C}_{4} \mathrm{~F}_{9} \mathrm{CO}_{2}\right],>99 \%\right.$ mass fraction purity) were previously synthesized and characterized in our laboratory $[31,56,57]$.

To reduce volatile chemicals and water contents, all FILs were dried under vacuum (4 Pa) with vigorous stirring at about $40^{\circ} \mathrm{C}$ for at least $48 \mathrm{~h}$ before their use. The purity of all FILs was checked by ${ }^{1} \mathrm{H}$ and ${ }^{19} \mathrm{~F}$ NMR. The chemical structures of the fluorinated ionic liquids used in this work are presented in Table 1.

The bacterial strain Pseudomonas stutzeri (ATCC 17588) was purchased from ATCC (Manassas, VA, USA). Tablets for the phosphate buffered saline (PBS) solution preparation were purchased from PanReac Applichem ITW Reagents Division (Chicago, IL, USA). Milli-Q water (obtained from a Milli-Q Integral water purification system from Merck, Darmstadt, Germany) was used for the PBS and medium preparation of samples to be used in the microbial and hemocompatibility studies.

Table 1. Chemical structure and acronyms of the fluorinated ionic liquids (FILs) used in this work.

\begin{tabular}{ccc}
\hline FIL Designation \\
$\begin{array}{c}\text { 1-Ethyl-3-methylimidazolium } \\
\text { perfluoromethanesulfonate }\left[\mathrm{C}_{2} \mathrm{C}_{1} \mathrm{Im}\right]\left[\mathrm{CF}_{3} \mathrm{SO}_{3}\right]\end{array}$
\end{tabular}


Table 1. Cont.

\begin{tabular}{|c|c|}
\hline FIL Designation & Chemical Structure \\
\hline \multicolumn{2}{|l|}{$\begin{array}{l}\text { 1-Methyl-3-octylimidazolium } \\
\text { perfluoromethanesulfonate }\left[\mathrm{C}_{8} \mathrm{C}_{1} \mathrm{Im}\right]\left[\mathrm{CF}_{3} \mathrm{SO}_{3}\right]\end{array}$} \\
\hline \multicolumn{2}{|l|}{$\begin{array}{l}\text { 1-Ethyl-3-methylimidazolium } \\
\text { perfluorobutanesulfonate }\left[\mathrm{C}_{2} \mathrm{C}_{1} \mathrm{Im}\right]\left[\mathrm{C}_{4} \mathrm{~F}_{9} \mathrm{SO}_{3}\right]\end{array}$} \\
\hline \multicolumn{2}{|l|}{$\begin{array}{l}\text { 1-Methyl-3-octylimidazolium } \\
\text { perfluorobutanesulfonate }\left[\mathrm{C}_{8} \mathrm{C}_{1} \mathrm{Im}\right]\left[\mathrm{C}_{4} \mathrm{~F}_{9} \mathrm{SO}_{3}\right]\end{array}$} \\
\hline \multicolumn{2}{|l|}{$\begin{array}{l}\text { 1-Ethyl-3-methylpyridinium } \\
\text { perfluorobutanesulfonate or 1-ethyl-3-picolinium } \\
\text { perfluorobutanesulfonate }\left[\mathrm{C}_{2} \mathrm{C}_{1} \text { py }\right]\left[\mathrm{C}_{4} \mathrm{~F}_{9} \mathrm{SO}_{3}\right]\end{array}$} \\
\hline $\begin{array}{l}\text { Choline perfluorobutanesulfonate } \\
\qquad\left[\mathrm{N}_{1112(\mathrm{OH})}\right]\left[\mathrm{C}_{4} \mathrm{~F}_{9} \mathrm{SO}_{3}\right]\end{array}$ & \\
\hline \multicolumn{2}{|l|}{$\begin{array}{l}\text { 1-Ethyl-3-methylimidazolium perfluoropentanoate } \\
\qquad\left[\mathrm{C}_{2} \mathrm{C}_{1} \mathrm{Im}\right]\left[\mathrm{C}_{4} \mathrm{~F}_{9} \mathrm{CO}_{2}\right]\end{array}$} \\
\hline \multicolumn{2}{|l|}{$\begin{array}{l}\text { 1-Ethyl-3-methylpyridinium perfluoropentanoate } \\
\qquad\left[\mathrm{C}_{2} \mathrm{C}_{1} \text { py }\right]\left[\mathrm{C}_{4} \mathrm{~F}_{9} \mathrm{CO}_{2}\right]\end{array}$} \\
\hline Choline perfluoropentanoate $\left[\mathrm{N}_{1112(\mathrm{OH})}\right]\left[\mathrm{C}_{4} \mathrm{~F}_{9} \mathrm{CO}_{2}\right]$ & \\
\hline
\end{tabular}

\subsection{Methods}

\subsubsection{Ecotoxicity-Antibacterial Activity}

Bacteria were firstly cultured in a specific broth for $24 \mathrm{~h}$ at $37^{\circ} \mathrm{C}$ in an orbital shaker at $150 \mathrm{rpm}$. The flasks were inoculated $(3 \% v / v)$ with previously obtained cell pellets. The composition of the broth media for the bacteria growth is $(\mathrm{g} / \mathrm{L}): 1.0$ beef extract; 2.0 yeast extract; 5.0 casein peptone; and 5.0 sodium chloride. The bacterial growth was then evaluated in a mineral medium (MM) with the following composition $(\mathrm{g} / \mathrm{L}): \mathrm{Na}_{2} \mathrm{HPO}_{4}$ 6.78, $\mathrm{KH}_{2} \mathrm{PO}_{4}$ 3.0, $\mathrm{NaCl} 0.5, \mathrm{NH}_{4} \mathrm{Cl} 1.0, \mathrm{MgSO}_{4} \cdot 7 \mathrm{H}_{2} \mathrm{O} 0.5, \mathrm{CaCl}_{2}$ 0.0147. Trace elements are also included in $\mathrm{MM}(\mathrm{g} / \mathrm{L}): \mathrm{CuSO}_{4} 0.4, \mathrm{KI} 1.0, \mathrm{MnSO}_{4} \cdot \mathrm{H}_{2} \mathrm{O}$ 4.0, $\mathrm{ZnSO}_{4} \cdot 7 \mathrm{H}_{2} \mathrm{O}$ 4.0, $\mathrm{H}_{3} \mathrm{BO}_{3}$ 5.0, 1.6, $\mathrm{FeCl}_{3} \cdot 6 \mathrm{H}_{2} \mathrm{O}$ 2.0. Glucose, $10 \mathrm{~g} / \mathrm{L}$, were included in the culture medium as a carbon source. Several FILs were firstly diluted in miliQ water to obtain the final test concentrations ranging from 500 to $800,000 \mu \mathrm{M}$. The antibacterial activity of these FILs 
was determined incubating the microorganism, the MM and the FILs solutions in 96-well plates. The bacteria growth was measured photometrically at $600 \mathrm{~nm}$ in a Multiskan ${ }^{\mathrm{TM}} \mathrm{GO}$ microplate reader purchased from Thermo Scientific (Waltham, MA, USA) after incubation at $37^{\circ} \mathrm{C}$ for 9 days. Negative controls containing only P. stutzeri and the MM and positive controls containing only the MM were conducted under the same conditions. The screening along the different FIL concentrations enabled the determination of the minimal inhibitory concentration (MIC) defined as the lowest concentration that inhibits the visible growth of the bacteria. For an accurate determination of these values, the bacterial growth was determined for all the tested samples relative to the maximum growth $(100 \%)$ obtained for the samples containing only bacteria and the MM. Calculations were made based on the maximum growth achieved after 9 days for each FIL concentration. For samples with a relative growth under $10 \%$, the MIC was selected. The experiments were performed at least twice with a maximum standard deviation of $12 \%$.

\subsubsection{Hemolytic Activity}

The hemolytic activity of the different FILs was determined according to the method optimized by Gaspar and co-workers using ethylene diamine tetraacetic acid (EDTA)preserved peripheral human blood obtained from voluntary donors used in the same day of experiments $[58,59]$. To separate the serum from the erythrocytes, a centrifugation was performed at $1000 \times g$ for $10 \mathrm{~min}$. Then, the erythrocyte suspension was washed three times in a phosphate buffered saline (PBS) solution. All FILs were diluted in PBS with concentrations ranging from 166 to $266,092 \mu \mathrm{M}$. The assay was performed in 96-well plates, in which $100 \mu \mathrm{L} /$ well of sample were diluted with $100 \mu \mathrm{L}$ of the erythrocyte suspension. The microplates were incubated at $37^{\circ} \mathrm{C}$ for $1 \mathrm{~h}$ followed by a centrifugation at $800 \times g$ for $10 \mathrm{~min}$. The absorbance of supernatants was measured at $570 \mathrm{~nm}$ and $630 \mathrm{~nm}$. The percentage of the hemolytic activity for each sample was calculated by subtracting the values at $630 \mathrm{~nm}$ to the values at $570 \mathrm{~nm}$ and comparing each individual sample to a positive control (100\% hemolysis, erythrocytes in distilled water), and to a negative control ( $0 \%$ hemolysis, erythrocytes in PBS), according to following formula:

$$
\text { Hemolytic Activity }(\%)=\frac{\mathrm{AbsS}-\mathrm{AbsN}}{\mathrm{AbsP}-\mathrm{AbsN}} \times 100
$$

where AbsS is the average absorbance of the sample, AbsN is the average absorbance of the negative control and AbsP is the average absorbance of the positive control.

\section{Results}

\subsection{Ecotoxicity-Antibacterial Activity}

It is well known that the IL toxicity is highly dependent and variable with the biologically tested system [22]. Then, this work provides critical insights about FIL ecotoxicity and antibacterial properties towards the highly dispersed Gram-negative P. stutzeri bacteria. These bacteria are easily maintained at laboratorial conditions, which eases the experimental procedure. Afterwards, several structure-activity relationships will be considered for analysis, such as the effect of the: (a) cation family (imidazolium, pyridinium and choline); (b) anion nature (perfluorobutanesulfonate and perfluoropentanoate); (c) alkyl side chain length; and (d) fluorinated side chain length. The bacterial growth curves used to determine the MIC value were stablished for all tested FIL concentrations regarding the maximum growth of negative controls, and some examples are depicted in Figures S1-S4 (in Supplementary Materials). The MIC values of the tested compounds are shown in Figures 1 and 2 and indicated in Table S1. These values range from $>2930$ to 400,000 $\mu \mathrm{M}$, which corroborates the already demonstrated ecofriendly nature of FILs [31]. 


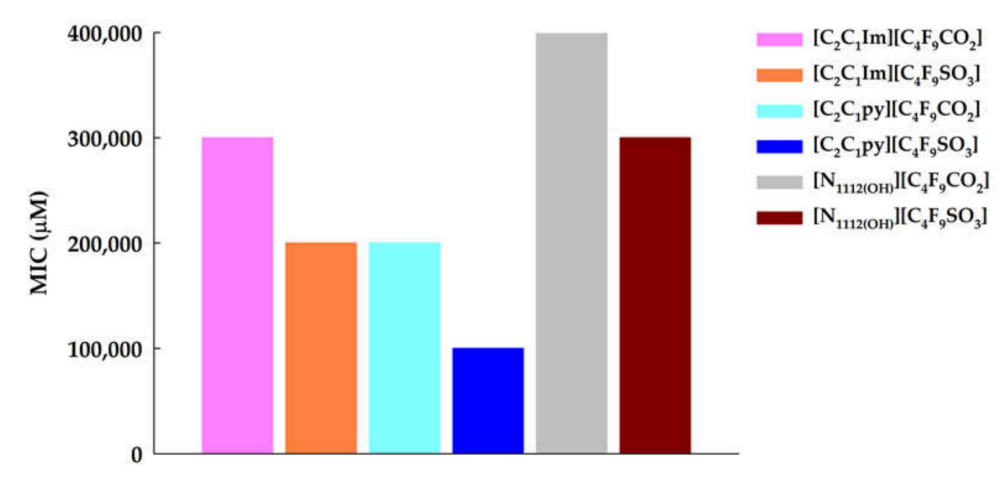

Figure 1. Minimal inhibitory concentration (MIC) values determined for choline, and short hydrogenated alkyl side chain imidazolium and pyridinium cations conjugated with perfluorobutanesulfonate $\left(\left[\mathrm{C}_{4} \mathrm{~F}_{9} \mathrm{SO}_{3}\right]^{-}\right)$or perfluoropentanoate anion $\left(\left[\mathrm{C}_{4} \mathrm{~F}_{9} \mathrm{CO}_{2}\right]^{-}\right)$.

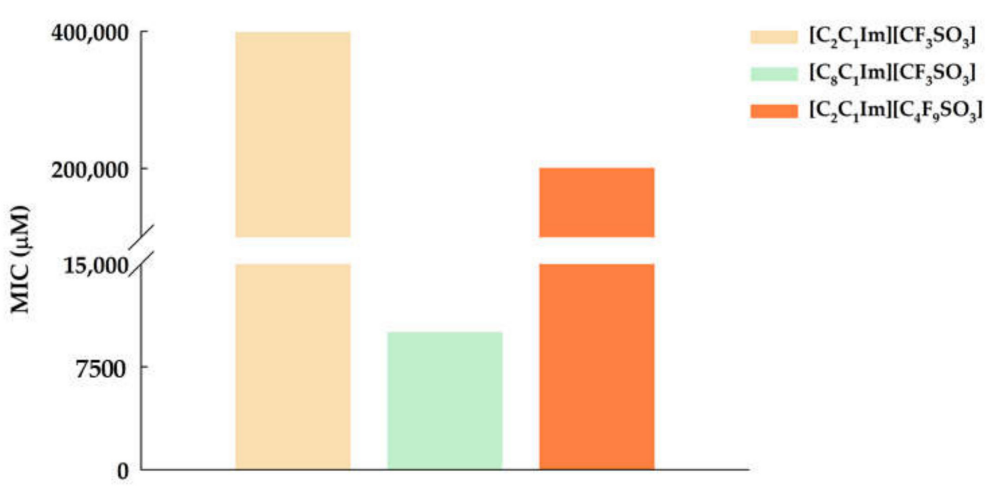

Figure 2. MIC values determined for imidazolium-based fluorinated ionic liquids (FILs) conjugated with the sulfonate-based anion with the increment of both the hydrogenated and fluorinated alkyl side chain length.

The effect of the choline and the short chain-based imidazolium and pyridinium cations conjugated with either perfluorobutanesulfonate $\left(\left[\mathrm{C}_{4} \mathrm{~F}_{9} \mathrm{SO}_{3}\right]^{-}\right)$or perfluoropentanoate $\left(\left[\mathrm{C}_{4} \mathrm{~F}_{9} \mathrm{CO}_{2}\right]^{-}\right)$anions on the bacterial growth and in the determined MIC value, are shown in Table S1 and depicted in Figure 1.

According to the obtained results, when conjugated with the $\left[\mathrm{C}_{4} \mathrm{~F}_{9} \mathrm{SO}_{3}\right]^{-}$the choline cation is the least toxic cation, with a MIC value of $300,000 \mu \mathrm{M}$, followed by the imidazoliumbased cation in which the visible growth of bacteria is limited at a concentration equal or higher than 200,000 $\mu \mathrm{M}$. Lastly, the higher toxicity is achieved with the pyridinium cation, in which the MIC is achieved at a concentration of $100,000 \mu \mathrm{M}$. The same trend was observed with the $\left[\mathrm{C}_{4} \mathrm{~F}_{9} \mathrm{CO}_{2}\right]^{-}$, however, the values of the MICs for the carboxylate-based FILs were consistently $100,000 \mu \mathrm{M}$ higher than those obtained for the $\left[\mathrm{C}_{4} \mathrm{~F}_{9} \mathrm{SO}_{3}\right]^{-}$, which means that compounds based on this anion are relatively less toxic than the $\left[\mathrm{C}_{4} \mathrm{~F}_{9} \mathrm{SO}_{3}\right]^{-}$-based FILs. The differences amongst the choline, imidazolium and pyridinium cations are in the same order as the differences between the carboxylic and the sulfonic-based fluoroorganic anions. Both imidazolium and choline compounds conjugated with $\left[\mathrm{C}_{4} \mathrm{~F}_{9} \mathrm{SO}_{3}\right]^{-}$and $\left[\mathrm{C}_{4} \mathrm{~F}_{9} \mathrm{CO}_{2}\right]^{-}$ were previously tested against the Gram-negative bacteria $V$. fischeri, with lower toxicities achieved for the choline-based cation, and for the carboxylate-based anions [31]. In this previous study, the pyridinium cation was the most toxic compound amongst the $\left[\mathrm{C}_{4} \mathrm{~F}_{9} \mathrm{CO}_{2}\right]^{-}$-based FILs, following the same trend observed for P. stutzeri, although the differences between pyridinium, choline and imidazolium compounds are less evidenced for $P$. stutzeri than for $V$. fischeri, which can be associated to intrinsic differences between the microorganisms [31]. The increment of the alkyl side chain length from $\left[\mathrm{C}_{2} \mathrm{C}_{1} \mathrm{Im}\right]^{+}$ to $\left[\mathrm{C}_{8} \mathrm{C}_{1} \mathrm{Im}\right]^{+}$in both $\left[\mathrm{CF}_{3} \mathrm{SO}_{3}\right]^{-}$and $\left[\mathrm{C}_{4} \mathrm{~F}_{9} \mathrm{SO}_{3}\right]^{-}$caused a significant reduction on the 
MIC value, as shown in Table S1, Figure 2 and Figures S1-S4. $\left[\mathrm{C}_{2} \mathrm{C}_{1} \mathrm{Im}\right]\left[\mathrm{CF}_{3} \mathrm{SO}_{3}\right]$ have a MIC value of $400,000 \mu \mathrm{M}$, which is reduced to $10,000 \mu \mathrm{M}$ when the side chain increases to $\left[\mathrm{C}_{8} \mathrm{C}_{1} \mathrm{Im}\right]\left[\mathrm{CF}_{3} \mathrm{SO}_{3}\right]$. The same trend was expected to be achieved with the $\left[\mathrm{C}_{4} \mathrm{~F}_{9} \mathrm{SO}_{3}\right]^{-}$, however, at the range of tested concentrations, it was not possible to determine the MIC value. Concentrations higher than $2930 \mu \mathrm{M}$ were not tested due to the poor solubility of $\left[\mathrm{C}_{8} \mathrm{C}_{1} \mathrm{Im}\right]\left[\mathrm{C}_{4} \mathrm{~F}_{9} \mathrm{SO}_{3}\right]$ in the bacterial growth medium. Nevertheless, as depicted in Figures S3 and $\mathrm{S} 4$, for $\left[\mathrm{C}_{8} \mathrm{C}_{1} \mathrm{Im}\right]\left[\mathrm{C}_{4} \mathrm{~F}_{9} \mathrm{SO}_{3}\right]$ at this maximum tested concentration $(2930 \mu \mathrm{M})$, the achieved bacterial growth is slightly lower than $50 \%$, whereas in $\left[C_{2} C_{1} \operatorname{Im}\right]\left[C_{4} F_{9} S_{3}\right]$ for concentrations up to $5000 \mu \mathrm{M}$ the bacterial growth is slightly higher than $95 \%$, which is in accordance to the results achieved for the $\left[\mathrm{CF}_{3} \mathrm{SO}_{3}\right]^{-}$-based FILs. This higher antibacterial activity caused by the elongation of the hydrogenated side chain was linked to the increment of the hydrophobicity and is consistently reported in several cell cultures and microorganisms, including several Gram-negative bacteria [22,39,46,60].

The increment of the fluorinated chain from $\left[\mathrm{CF}_{3} \mathrm{SO}_{3}\right]^{-}$to $\left[\mathrm{C}_{4} \mathrm{~F}_{9} \mathrm{SO}_{3}\right]^{-}$also impacted the ecotoxicity of the FILs towards P. stutzeri bacteria, with higher toxicities obtained for the longer fluorinated anions. Even so, the increment of the fluorinated chain has a less pronounced effect on the MIC values of FILs than the increment of the hydrogenated side chain length of the cation.

For the short chain-based imidazolium $\left(\left[\mathrm{C}_{2} \mathrm{C}_{1} \mathrm{Im}\right]^{+}\right)$, the increment of the fluorinated chain from $\left[\mathrm{CF}_{3} \mathrm{SO}_{3}\right]^{-}$to $\left[\mathrm{C}_{4} \mathrm{~F}_{3} \mathrm{SO}_{3}\right]^{-}$caused a decrement of the MIC value from 400,000 to $200,000 \mu \mathrm{M}$. For the $\left[\mathrm{C}_{8} \mathrm{C}_{1} \mathrm{Im}\right]^{+}$-based FIL, the increment of the fluorinated chain for $\left[\mathrm{C}_{4} \mathrm{~F}_{3} \mathrm{SO}_{3}\right]^{-}$impacted the solubility of the FIL. As illustrated in Figure S4, and as mentioned before, for the maximum tested concentration of $\left[\mathrm{C}_{8} \mathrm{C}_{1} \mathrm{Im}\right]\left[\mathrm{C}_{4} \mathrm{~F}_{9} \mathrm{SO}_{3}\right]$, the relative bacterial growth is slightly below $50 \%$, whereas for a concentration of $5000 \mu \mathrm{M}$ in $\left[\mathrm{C}_{8} \mathrm{C}_{1} \mathrm{Im}\right]\left[\mathrm{CF}_{3} \mathrm{SO}_{3}\right]$, as illustrated in Figure S2, the bacterial growth is $80 \%$. Although less is known about the anion effect on ILs, it was also proved that the anion elongation also increases the hydrophobicity of the compounds, and consequently its toxicity towards different organisms, including human pathogenic bacteria $[39,46,61,62]$. Based on these results, the better antibacterial potential was achieved for $\left[\mathrm{C}_{8} \mathrm{C}_{1} \mathrm{Im}\right]\left[\mathrm{CF}_{3} \mathrm{SO}_{3}\right]$, which inhibits the growth of these microorganisms at concentrations approximately 10 times lower than the other tested FILs, and can represent a treatment alternative to the antibiotics commonly administered. Even so, all determined MICs correspond to very high concentrations which corroborates the ecofriendly nature of these compounds, as already demonstrated for other aquatic microorganisms. This reduced toxicity towards $P$. stutzeri can be related to the structure of the Gram-negative bacteria which possess several membrane layers that confers them an additional protection against the external stimuli, such as FILs [31,63,64].

\subsection{Hemolytic Activity}

An in vitro hemolysis study must be performed prior to any pharmaceutical application of FILs in order to guarantee their biocompatibility and to follow the Food and Drug Administration (FDA) recommendations for the development of compounds for intravenous or parenteral administration [59]. This study evaluates the red blood cell lysis through the hemoglobin release in the plasma, for FIL concentrations up to $266,092 \mu \mathrm{M}$. The hemolytic activity of the different FILs was analyzed regarding the: (a) cation family (imidazolium, pyridinium and choline); (b) anion nature (perfluorobutanesulfonate and perfluoropentanoate); (c) alkyl side chain length; and (d) fluorinated side chain length.

As shown in Table S2 and as depicted in Figures 3 and 4, the cytotoxicity towards the red blood cells was achieved at very high concentrations of FIL. Furthermore, as shown in Figure 3, contrary to the expected and noticed in the antibacterial, acute aquatic toxicity and prior cytotoxicity studies $[31,46]$, a higher hemolytic activity was obtained for the cholinebased FILs, particularly for $\left[\mathrm{N}_{1112(\mathrm{OH})}\right]\left[\mathrm{C}_{4} \mathrm{~F}_{9} \mathrm{CO}_{2}\right]^{-}$. These results can be associated to the type of structures formed by these specific choline-based FILs, at concentrations higher than the critical micellar concentration (CMC) $[43,45]$, that may interact with the cellular membrane, causing its disruption and leading to a higher hemolysis in comparison to the 
other FILs. The lower $\mathrm{CMC}$ of $\left[\mathrm{N}_{1112(\mathrm{OH})}\right]\left[\mathrm{C}_{4} \mathrm{~F}_{9} \mathrm{CO}_{2}\right]$ in comparison to $\left[\mathrm{N}_{1112(\mathrm{OH})}\right]\left[\mathrm{C}_{4} \mathrm{~F}_{9} \mathrm{SO}_{3}\right]$ justifies the higher hemolytic activity of $\left[\mathrm{N}_{1112(\mathrm{OH})}\right]\left[\mathrm{C}_{4} \mathrm{~F}_{9} \mathrm{CO}_{2}\right]$ at similar concentrations than the correspondent perfluorobutanesulfonate FIL [43,45]. Nevertheless, a considerable hemolysis was only achieved at extremely high FIL concentrations (see Table S2).

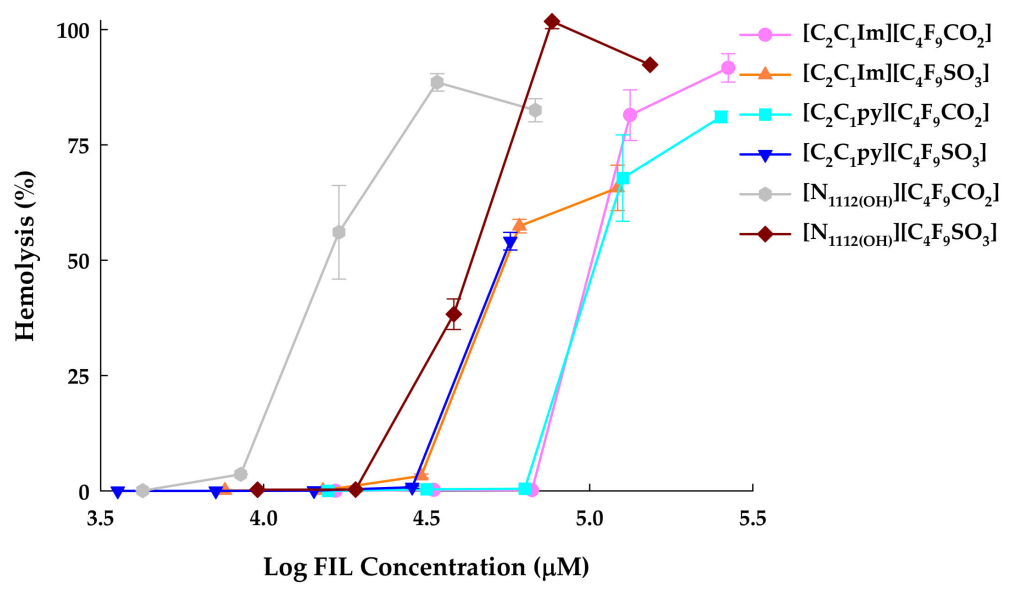

Figure 3. Hemolysis (\%) determined for choline, and short hydrogenated alkyl side chain imidazolium and pyridinium cations conjugated with perfluorobutanesulfonate $\left(\left[\mathrm{C}_{4} \mathrm{~F}_{9} \mathrm{SO}_{3}\right]^{-}\right)$or perfluoropentanoate anion $\left(\left[\mathrm{C}_{4} \mathrm{~F}_{9} \mathrm{CO}_{2}\right]^{-}\right)$.

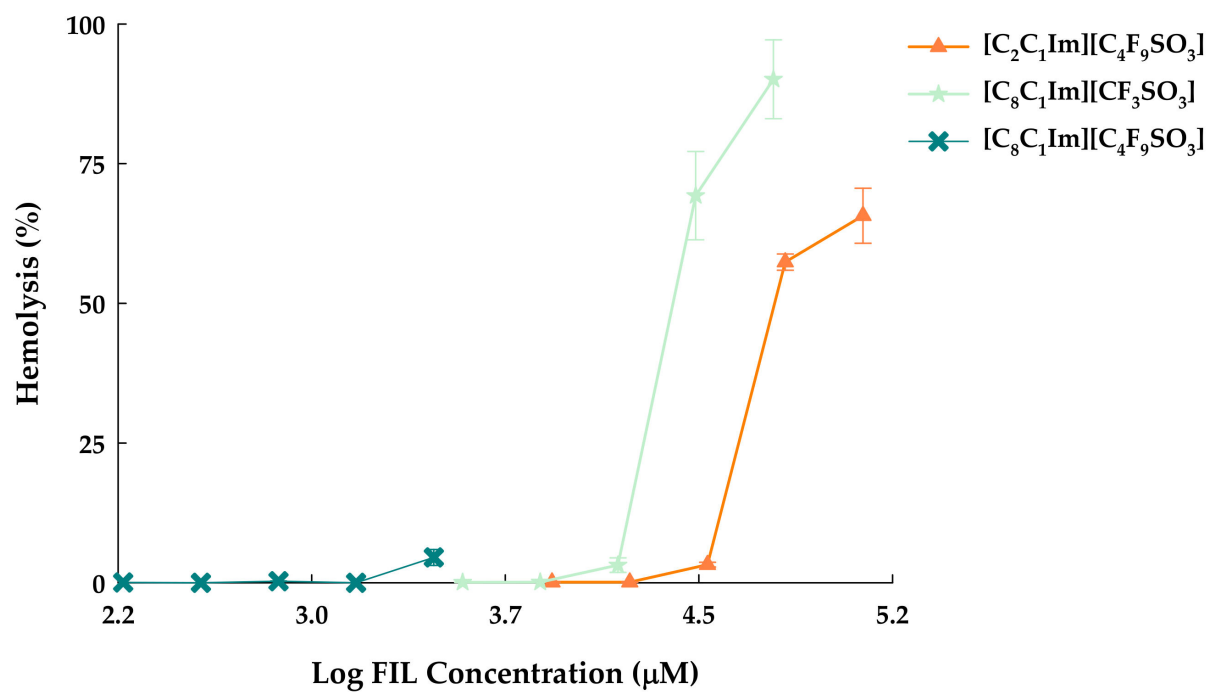

Figure 4. Hemolysis (\%) determined for imidazolium-based FILs conjugated with the sulfonic-based anion with the increment of both hydrogenated and fluorinated alkyl side chain length.

No substantial differences were noticed between $\left[\mathrm{C}_{2} \mathrm{C}_{1} \mathrm{Im}\right]^{+}$and $\left[\mathrm{C}_{2} \mathrm{C}_{1} \text { py }\right]^{+}$cations when conjugated with both perfluorobutanesulfonate or perfluoropentanoate anions. Even so, the lowest hemolytic activity was achieved for $\left[\mathrm{C}_{2} \mathrm{C}_{1}\right.$ py] $\left[\mathrm{C}_{4} \mathrm{~F}_{9} \mathrm{CO}_{2}\right]$, followed by $\left[\mathrm{C}_{2} \mathrm{C}_{1} \mathrm{Im}\right]\left[\mathrm{C}_{4} \mathrm{~F}_{9} \mathrm{CO}_{2}\right]$, without significant variances amongst the two compounds.

The hemolysis was achieved at lower concentrations for $\left[\mathrm{C}_{4} \mathrm{~F}_{9} \mathrm{SO}_{3}\right]^{-}$-based FILs than for the ones based on the $\left[\mathrm{C}_{4} \mathrm{~F}_{9} \mathrm{CO}_{2}\right]^{-}$anion, except for choline-based FILs, which demonstrated an opposite trend. Due to the poor solubility of $\left[\mathrm{C}_{8} \mathrm{C}_{1} \mathrm{Im}\right]\left[\mathrm{C}_{4} \mathrm{~F}_{9} \mathrm{SO}_{3}\right]$ in $\mathrm{PBS}$, it was not possible to determine at which concentration a considerable hemolytic activity occurs, which makes a proper evaluation about the influence of alkyl and fluorinated side chain length in the FILs toxicity difficult. However, based on the profiles depicted in Figure 4, and on the knowledge about the effect of the cationic and anionic side chain elongation, it is expected that the increment from $\left[\mathrm{C}_{2} \mathrm{C}_{1} \mathrm{Im}\right]\left[\mathrm{C}_{4} \mathrm{~F}_{9} \mathrm{SO}_{3}\right]$ or $\left[\mathrm{C}_{8} \mathrm{C}_{1} \mathrm{Im}\right]\left[\mathrm{CF}_{3} \mathrm{SO}_{3}\right]$ to 
$\left[\mathrm{C}_{8} \mathrm{C}_{1} \mathrm{Im}\right]\left[\mathrm{C}_{4} \mathrm{~F}_{9} \mathrm{SO}_{3}\right]$ induces an increment on the FIL hemolytic activity, and consequently on the FIL toxicity. This increased toxicity is associated to the increment of the hydrophobicity that may contribute to a higher permeation or disruption of cell membranes, and the destabilization of the cellular viability mechanisms [46,65-68]. The overall obtained results support the application of FILs in the pharmaceutical field (such as stabilizing or delivery agents), since a considerable red blood cell lysis only occurs at concentrations higher or close to the CMC [43-45]. These CMCs are used as reference for the design of delivery systems. For the imidazolium and pyridinium-based FILs conjugated with the perfluorobutanesulfonate anion and for $\left[\mathrm{C}_{2} \mathrm{C}_{1} \mathrm{Im}\right]\left[\mathrm{C}_{4} \mathrm{~F}_{9} \mathrm{CO}_{2}\right]$, the hemolysis occurs at concentrations higher than two times the $\mathrm{CMC}$, in which the encapsulation of lysozyme was already demonstrated [47]. Furthermore, based on the hemolytic activity of the different FILs, it becomes clear that $\left[\mathrm{C}_{8} \mathrm{C}_{1} \mathrm{Im}\right]\left[\mathrm{CF}_{3} \mathrm{SO}_{3}\right]$ is the only compound with the potential to be used as an antibacterial agent without affecting the integrity of red blood cells. The growth of $P$. stutzeri bacteria is inhibited at $10,000 \mu \mathrm{M}$, whereas at concentrations up to $13,697 \mu \mathrm{M}$, the hemolysis caused by this FIL is equal or lower than $3.15 \%$. For the other tested compounds, the MIC concentration is associated to a hemolysis always higher $50 \%$. Nevertheless, it must be reinforced that all compounds present relatively lower hemolytic activities up to high concentrations, which is a good indicator for their application in either biopharmaceutical or industrial applications, without prejudice of public health.

\section{Conclusions}

The results obtained in this work are vital for the characterization of the FIL family, for the design of new antibacterial compounds for the treatment of infections caused by P. stutzeri, as well as for the selection of ecofriendly FILs with low environmental impacts to be used in other pharmaceutical and industrial purposes.

Firstly, the results obtained support the ecofriendly nature of these compounds since the inhibition of the bacterial growth is only achieved at very high concentrations. The choline cation conjugated with the perfluoropentanoate anion exhibited the lowest ecotoxicity amongst all the tested FILs, as well as the perfluoropentanoate demonstrated to be the most ecofriendly anion. Besides, the increment of both hydrogenated and fluorinated alkyl side chain induced an increased ecotoxicity.

The hemolytic activity of these FILs reveals that the red blood cell lysis only occurs at very high concentrations, which corroborates their biocompatible nature. An atypical behavior was noticed with a highest toxicity associated to the choline-based FILs, namely $\left[\mathrm{N}_{1112(\mathrm{OH})}\right]\left[\mathrm{C}_{4} \mathrm{~F}_{9} \mathrm{CO}_{2}\right]$, so further studies must be carried out to better understand the mechanisms of cell lysis associated to these FILs. The biocompatibility of imidazolium and pyridinium-based FILs were very similar, and for these two cations a higher hemolytic activity was achieved with the perfluorobutanesulfonate anion. The higher toxicity expected with the elongation of the hydrogenated and fluorinated alkyl side chain was not fully proved due to the poor solubility of $\left[\mathrm{C}_{8} \mathrm{C}_{1} \mathrm{Im}\right]\left[\mathrm{C}_{4} \mathrm{~F}_{9} \mathrm{SO}_{3}\right]$. However, based on the obtained hemolysis profiles, it is clearly expected that $\left[\mathrm{C}_{8} \mathrm{C}_{1} \mathrm{Im}\right]\left[\mathrm{C}_{4} \mathrm{~F}_{9} \mathrm{SO}_{3}\right]$ will have the higher hemolytic activities at similar concentrations to the other imidazolium-based compounds.

Finally, $\left[\mathrm{C}_{8} \mathrm{C}_{1} \mathrm{Im}\right]\left[\mathrm{CF}_{3} \mathrm{SO}_{3}\right]$ was selected as the most promising FIL to be used as an antibacterial compound. This FIL can inhibit the bacterial growth at a lower concentration than the other tested compounds, without causing the hemolysis of red blood cells. Even so, the results obtained from the other tested FILs reveal the low ecotoxicity and the reduced cytotoxicity of FILs up to high concentrations, ensuring their safe application in other pharmaceutical and industrial applications.

Supplementary Materials: The following are available online at https:/ /www.mdpi.com/2673-4 079/2/1/8/s1, Table S1. MIC value of different FILs against Pseudomonas stutzeri in $\mu$ M, Table S2. Hemolysis (\%) as function of concentration determined for several FILs, Figure S1. Pseudomonas stutzeri growth curves for different concentrations of 1-ethyl-3-methylimidazolium perfluoromethanesulfonate $\left[\mathrm{C}_{2} \mathrm{C}_{1} \mathrm{Im}\right]\left[\mathrm{CF}_{3} \mathrm{SO}_{3}\right]$, Figure S2. Pseudomonas stutzeri growth curves for different concentrations of 1-methyl-3-octylimidazolium perfluoromethanesulfonate $\left[\mathrm{C}_{8} \mathrm{C}_{1} \mathrm{Im}\right]\left[\mathrm{CF}_{3} \mathrm{SO}_{3}\right]$, FigureS3. 
Pseudomonas stutzeri growth curves for different concentrations of 1-ethyl-3-methylimidazolium perfluorobutanesulfonate $\left[\mathrm{C}_{2} \mathrm{C}_{1} \mathrm{Im}\right]\left[\mathrm{C}_{4} \mathrm{~F}_{9} \mathrm{SO}_{3}\right]$, Figure S4. Pseudomonas stutzeri growth curves for different concentrations of 1-methyl-3-octylimidazolium perfluorobutanesulfonate $\left[\mathrm{C}_{8} \mathrm{C}_{1} \mathrm{Im}\right]\left[\mathrm{C}_{4} \mathrm{~F}_{9} \mathrm{SO}_{3}\right]$.

Author Contributions: Conceptualization, A.B.P. and N.S.M.V.; methodology, N.S.M.V., A.L.S.O., M.M.G.; validation, A.B.P., M.M.G., N.S.M.V.; formal analysis, A.B.P., M.M.G., N.S.M.V.; investigation, N.S.M.V., A.L.S.O., M.M.G., J.M.M.A., and A.B.P.; resources, A.B.P., J.M.M.A. and M.M.G.; data curation, A.B.P., M.M.G., N.S.M.V., and A.L.S.O.; writing-original draft preparation, N.S.M.V.; writing-review and editing, A.B.P., M.M.G., J.M.M.A.; supervision, A.B.P., M.M.G., J.M.M.A.; project administration, A.B.P. and J.M.M.A.; funding acquisition, M.M.G., A.B.P. and J.M.M.A. All authors have read and agreed to the published version of the manuscript.

Funding: This work was financially supported by FCT/MEC (Portugal), through project PTDC/EQUEQU/29737/2017 and projects UIDB/04138/2020 and UIDP/04138/2020. This work was also supported by the Associate Laboratory for Green Chemistry-LAQV-which is financed by national funds from FCT/MCTES (UIDB/50006/2020).

Data Availability Statement: The data presented in this study are available on request from the corresponding author.

Acknowledgments: The authors thank Fátima Moscoso Diaz for her collaboration in ecotoxicityantibacterial activity studies.

Conflicts of Interest: The authors declare no conflict of interest the results.

\section{References}

1. Padvi, S.A.; Dalal, D.S. Task-specific Ionic Liquids as a Green Catalysts and Solvents for Organic Synthesis. Curr. Green Chem. 2020, 7, 105-119. [CrossRef]

2. Qiao, Y.; Ma, W.; Chen, C.; Hou, Z. Temperature-responsive ionic liquids: Fundamental behaviors and catalytic applications. Chem. Rev. 2017, 117, 6881-6928. [CrossRef] [PubMed]

3. Guglielmero, L.; Mezzetta, A.; Pomelli, C.S.; Chiappe, C.; Guazzelli, L. Evaluation of the effect of the dicationic ionic liquid structure on the cycloaddition of $\mathrm{CO}_{2}$ to epoxides. J. CO2 Util. 2019, 34, 437-445. [CrossRef]

4. Watanabe, M.; Thomas, M.L.; Zhang, S.; Ueno, K.; Yasuda, T.; Dokko, K. Application of ionic liquids to energy storage and conversion materials and devices. Chem. Rev. 2017, 117, 7190-7239. [CrossRef] [PubMed]

5. Cai, M.; Yu, Q.; Liu, W.; Zhou, F. Ionic liquid lubricants: When chemistry meets tribology. Chem. Soc. Rev. 2020, 49, 7753-7818. [CrossRef]

6. Chen, K.; Shi, G.; Zhou, X.; Li, H.; Wang, C. Highly Efficient Nitric Oxide Capture by Azole-Based Ionic Liquids through Multiple-Site Absorption. Angew. Chem. 2016, 128, 14576-14580. [CrossRef]

7. Ventura, S.P.M.; e Silva, F.A.; Quental, M.V.; Mondal, D.; Freire, M.G.; Coutinho, J.A.P. Ionic-liquid-mediated extraction and separation processes for bioactive compounds: Past, present, and future trends. Chem. Rev. 2017, 117, 6984-7052. [CrossRef] [PubMed]

8. Wu, D.; Cai, P.; Zhao, X.; Kong, Y.; Pan, Y. Recent progress of task-specific ionic liquids in chiral resolution and extraction of biological samples and metal ions. J. Sep. Sci. 2018, 41, 373-384. [CrossRef]

9. Skoronsk, E.; Fernandes, M.; Malaret, F.J.; Hallet, J.P. Use of phosphonium ionic liquids for highly efficient extraction of phenolic compounds from water. Sep. Purif. Technol. 2020, 248, 117069. [CrossRef]

10. Cui, J.; Li, Y.; Chen, D.; Zhan, T.; Zhang, K. Ionic Liquid-Based Stimuli-Responsive Functional Materials. Adv. Funct. Mater. 2020, 30, 2005522. [CrossRef]

11. Rehman, A.; Zeng, X. Ionic Liquids as Green Solvents and Electrolytes for Robust Chemical Sensor Development. Acc. Chem. Res. 2012, 45, 1667-1677. [CrossRef] [PubMed]

12. Huang, W.; Wu, X.; Qi, J.; Zhu, Q.; Wu, W.; Lu, Y.; Chen, Z. Ionic liquids: Green and tailor-made.solvents in drug delivery. Drug Discov. Today 2020, 25, 901-908. [CrossRef] [PubMed]

13. Agatemor, C.; Ibsen, K.N.; Tanner, E.E.L.; Mitragotri, S. Ionic liquids for addressing unmet needs in healthcare. Bioeng. Transl. Med. 2017, 3, 7-25. [CrossRef] [PubMed]

14. Egorova, K.S.; Gordeev, E.G.; Ananikov, V.P. Biological activity of ionic liquids and their application in pharmaceutics and medicine. Chem. Rev. 2017, 117, 7132-7189. [CrossRef] [PubMed]

15. Pendleton, J.N.; Gilmore, B.F. The antimicrobial potential of ionic liquids: A source of chemical diversity for infection and biofilm control. Int. J. Antimicrob. Agents 2015, 46, 131-139. [CrossRef]

16. Ferraz, R.; Branco, L.C.; Prudêncio, C.; Noronha, J.P.; Petrovski, Z. Ionic Liquids as Active Pharmaceutical Ingredients. ChemMedChem 2011, 6, 975-985. [CrossRef] [PubMed]

17. Lv, X.; Chen, K.; Shi, G.; Lin, W.; Bai, H.; Li, H.; Tang, G.; Wang, C. Design and tuning of ionic liquid-based HNO donor through intramolecular hydrogen bond for efficient inhibition of tumor growth. Sci. Adv. 2020, 6, eabb7788. [CrossRef] [PubMed] 
18. Rogers, R.D.; Seddon, K.R. Ionic liquids-Solvents of the future? Science 2003, 302, 792-793. [CrossRef] [PubMed]

19. Earle, M.J.; Esperança, J.M.S.S.; Gilea, M.A.; Canongia Lopes, J.N.; Rebelo, L.P.N.; Magee, J.W.; Seddon, K.R.; Widegren, J.A. The distillation and volatility of ionic liquids. Nature 2006, 439, 831-834. [CrossRef]

20. Mezzetta, A.; Perillo, V.; Guazzelli, L.; Chiape, C. Thermal behavior analysis as a valuable tool for comparing ionic liquids of different classes. J. Therm. Anal. Calorim. 2019, 138, 3335-3345. [CrossRef]

21. Clarke, C.J.; Bui-Le, L.; Hallett, J.P.; Licence, P. Thermally Stable Imidazolium Dicationic Ionic Liquids with Pyridine Functional Groups. ACS Sustain. Chem. Eng. 2020, 8, 8762-8772. [CrossRef]

22. Egorova, K.S.; Ananikov, V.P. Toxicity of Ionic Liquids: Eco(cyto)activity as complicated, but unavoidable parameter for taskspecific optimization. ChemSusChem 2014, 7, 336-360. [CrossRef] [PubMed]

23. Egorova, K.S.; Ananikov, V.P. Fundamental importance of ionic interactions in the liquid phase: A review of recent studies of ionic liquids in biomedical and pharmaceutical applications. J. Mol. Liq. 2018, 272, 271-300. [CrossRef]

24. Docherty, K.M.; Kulpa, J.C.F. Toxicity and Antimicrobial Activity of Imidazolium and Pyridinium Ionic Liquids. Green Chem. 2005, 7, 185-189. [CrossRef]

25. Fojtášková, J.; Koutník, I.; Vráblová, M.; Sezimová, H.; Maxa, M.; Obalová, L.; Pánek, P. Antibacterial, Antifungal and Ecotoxic Effects of Ammonium and Imidazolium Ionic Liquids Synthesized in Microwaves. Molecules 2020, 25, 5181. [CrossRef]

26. Cornellas, A.; Perez, L.; Comelles, F.; Ribosa, I.; Manresa, A.; Garcia, M.T. Self-Aggregation and Antimicrobial Activity of Imidazolium and Pyridinium Based Ionic Liquids in Aqueous Solution. J. Colloid Interface Sci. 2011, 355, 164-171. [CrossRef]

27. Florio, W.; Becherini, S.; D'Andrea, F.; Lupetti, A.; Chiappe, C.; Guazzelli, L. Comparative evaluation of antimicrobial activity of different types of ionicliquids. Mater. Sci. Eng. C 2019, 104, 109907. [CrossRef]

28. Demberelnyamba, D.; Kim, K.; Choi, S.; Park, S.; Lee, H.; Kim, C.; Yoo, I. Synthesis and antimicrobial properties of imidazolium and pyrrolidinonium salts. Bioorg. Med. Chem. 2004, 12, 853-857. [CrossRef]

29. Zheng, Z.; Xu, Q.; Guo, J.; Qin, J.; Mao, H.; Wang, B.; Yan, F. Structure-Antibacterial Activity Relationships of Imidazolium-Type Ionic Liquid Monomers, Poly(ionic liquids) and Poly(ionic liquid) Membranes: Effect of Alkyl Chain Length and Cations. ACS Appl. Mater. Interfaces 2016, 8, 12684-12692. [CrossRef]

30. Trush, M.M.; Semenyuta, I.V.; Vdovenko, S.I.; Rogalsky, S.P.; Lobko, E.O.; Metelytsia, L.O. Synthesis, spectroscopic and molecular docking studies of imidazolium and pyridinium based ionic liquids with HSA as potential antimicrobial agents. J. Mol. Struct. 2017, 137, 692-699. [CrossRef]

31. Vieira, N.S.M.; Stolte, S.; Araújo, J.M.M.; Rebelo, L.P.N.; Pereiro, A.B.; Markiewicz, M. Acute aquatic toxicity and biodegradability of fluorinated ionic liquids. ACS Sustain. Chem. Eng. 2019, 7, 3733-3741. [CrossRef]

32. Gilmore, B.F.; Andrews, G.P.; Borberly, G.; Earle, M.J.; Gilea, M.A.; Gorman, S.P.; Lowry, A.F.; McLaughlina, M.; Seddon, K.R. Enhanced antimicrobial activities of 1-alkyl-3-methylimidazolium ionic liquids based on silver or copper containing anions. New J. Chem. 2013, 37, 873. [CrossRef]

33. Carson, L.; Chau, P.K.W.; Earle, M.J.; Gilea, M.A.; Gilmore, B.F.; Gorman, S.P.; McCann, M.T.; Seddon, K.R. Antibiofilm activities of 1-alkyl-3-methylimidazolium chloride ionic liquids. Green Chem. 2009, 11, 492-497. [CrossRef]

34. Cole, M.R.; Li, M.; El-Zahab, B.; Janes, M.E.; Hayes, D.; Warner, I.M. Design, synthesis, and biological evaluation of $\beta$-lactam antibiotic-based imidazolium- and pyridinium-type ionic liquids. Chem. Biol. Drug Des. 2011, 78, 33-41. [CrossRef]

35. Álvarez, M.S.; Deive, F.J.; Sanromán, M.Á.; Rodríguez, A. Microbial Adaptation to Ionic Liquids Increases the "Talent" to Treat Contaminants. ACS Sustain. Chem. Eng. 2016, 4, 1637-1642. [CrossRef]

36. Ouellet, M.; Datta, S.; Dibble, D.C.; Tamrakar, P.R.; Benke, P.I.; Li, C.; Singh, S.; Sale, K.L.; Adams, P.D.; Keasling, J.D.; et al. Impact of ionic liquid pretreated plant biomass on Saccharomyces cerevisiae growth and biofuel production. Green Chem. 2011, 13, 2743-2749. [CrossRef]

37. Santos, A.G.; Ribeiro, B.D.; Alviano, D.S.; Coelho, M.A.Z. Toxicity of Ionic Liquids toward Microorganisms Interesting to the Food Industry. RSC Adv. 2014, 4, 37157-37163. [CrossRef]

38. Zhang, C.; Malhotra, S.V.; Francis, A.J. Toxicity of Ionic Liquids to Clostridium sp. and Effects on Uranium Biosorption. J. Hazard. Mater. 2014, 264, 246-253. [CrossRef] [PubMed]

39. Pereiro, A.B.; Araújo, J.M.M.; Martinho, S.; Alves, F.; Nunes, S.; Matias, A.; Duarte, C.M.M.; Rebelo, L.P.N.; Marrucho, I.M. Fluorinated ionic liquids: Properties and applications. ACS Sustain. Chem. Eng. 2013, 1, 427-439. [CrossRef]

40. Pereiro, A.B.; Pastoriza-Gallego, M.J.; Shimizu, K.; Marrucho, I.M.; Canongia Lopes, J.N.; Piñeiro, M.M.; Rebelo, L.P.N. On the Formation of a Third, Nanostructured Domain in Ionic Liquids. J. Phys. Chem. B 2013, 117, 10826-10833. [CrossRef] [PubMed]

41. Lindstrom, A.B.; Strynar, M.J.; Libelo, E.L.; Field, J.A. Guest comment: Perfluoroalkyl acid focus issue. Environ. Sci. Technol. 2011, 45, 7951-7953. [CrossRef]

42. Berger, R.; Resnati, G.; Metrangolo, P.; Weber, E.; Hulliger, J. Organic fluorine compounds: A great opportunity for enhanced materials properties. Chem. Soc. Rev. 2011, 40, 3496-3508. [CrossRef]

43. Pereiro, A.B.; Araújo, J.M.M.; Teixeira, F.S.; Marrucho, I.M.; Piñeiro, M.M.; Rebelo, L.P.N. Aggregation behavior and total miscibility of fluorinated ionic liquids in water. Langmuir 2015, 31, 1283-1295. [CrossRef] [PubMed]

44. Teixeira, F.S.; Vieira, N.S.M.; Cortes, O.A.; Araújo, J.M.M.; Marrucho, I.M.; Rebelo, L.P.N.; Pereiro, A.B. Phase equilibria and surfactant behavior of fluorinated ionic liquids with water. J. Chem. Thermodyn. 2015, 82, 99-107. [CrossRef]

45. Vieira, N.S.M.; Bastos, J.C.; Hermida-Merino, C.; Pastoriza-Gallego, M.J.; Rebelo, L.P.N.; Piñeiro, M.M.; Araújo, J.M.M.; Pereiro, A.B. Aggregation and phase equilibria of fluorinated ionic liquids. J. Mol. Liq. 2019, 285, 386-396. [CrossRef] 
46. Vieira, N.S.M.; Bastos, J.C.; Rebelo, L.P.N.; Matias, A.; Araújo, J.M.M.; Pereiro, A.B. Human cytotoxicity and octanol/water partition coefficients of fluorinated ionic liquids. Chemosphere 2019, 216, 576-586. [CrossRef]

47. Alves, M.; Vieira, N.S.M.; Rebelo, L.P.N.; Araújo, J.M.M.; Pereiro, A.B.; Archer, M. Fluorinated ionic liquids for protein drug delivery systems: Investigating their impact on the structure and function of lysozyme. Int. J. Pharm. 2017, 526, 309-320. [CrossRef]

48. Vieira, N.S.M.; Castro, P.J.; Marques, D.F.; Araújo, J.M.M.; Pereiro, A.B. Tailor-made fluorinated ionic liquids for protein delivery. Nanomaterials 2020, 10, 1594. [CrossRef]

49. Alves, M.; Araújo, J.M.M.; Martins, I.C.; Pereiro, A.B.; Archer, M. Insights into the interaction of bovine serum albumin with surface-active ionic liquids in aqueous solution. J. Mol. Liq. 2020, 332, 114537. [CrossRef]

50. Lalucat, J.; Bennasar, A.; Bosch, R.; García-Valdés, E.; Palleroni, N.J. Biology of Pseudomonas stutzeri. Microbiol. Mol. Biol. Rev. 2006, 70, 510-547. [CrossRef]

51. Waite, C.C.C.; Andrade da Silva, G.O.; Bitencourt, J.A.P.; Chequer, L.P.T.; Pennafirme, S.; Jurelevicius, D.A.; Seldin, L.; Crapez, M.A.C. Potential application of Pseudomonas stutzeri W228 for removal of copper and lead from marine environments. PLoS ONE 2020, 15, e0240486.

52. Moscoso, F.; Deive, F.J.; Longo, M.A.; Sanromán, M.A. Technoeconomic assessment of phenanthrene degradation by Pseudomonas stutzeri CECT 930 in a batch bioreactor. Bioresour. Technol. 2012, 104, 81-89. [CrossRef] [PubMed]

53. Moscoso, F.; Deive, F.J.; Villar, P.; Pena, R.; Herrero, L.; Longo, M.A.; Sanromán, M.A. Assessment of a process to degrade metal working fluids using Pseudomonas stutzeri CECT 930 and indigenous microbial consortia. Chemosphere 2012, 86, 420-426. [CrossRef] [PubMed]

54. Parthipan, P.; Narenkumar, J.; Elumalai, P.; Preethi, P.S.; Nanthini, A.U.R.; Agrawal, A.; Rajasekar, A. Neem extract as a green inhibitor for microbiologically influenced corrosion of carbon steel API 5LX in a hypersaline environments. J. Mol. Liq. 2017, 240, 121-127. [CrossRef]

55. Maalej, H.; Boisset, C.; Hmidet, N.; Colin-Morel, P.; Buon, L.; Nasri, M. Depolymerization of Pseudomonas stutzeri exopolysaccharide upon fermentation as a promising production process of antibacterial compounds. Food Chem. 2017, 227, 22-32. [CrossRef]

56. Vieira, N.S.M.; Reis, P.M.; Shimizu, K.; Cortes, A.O.; Marrucho, I.M.; Araújo, J.M.M.; Esperança, J.M.S.S.; Canongia Lopes, J.N.; Pereiro, A.B.; Rebelo, L.P.N. A thermophysical and structural characterization of ionic liquids with alkyl and perfluoroalkyl side chains. RSC Adv. 2015, 5, 65337-65350. [CrossRef]

57. Vieira, N.S.M.; Luís, A.; Reis, P.M.; Carvalho, P.J.; Lopes-da-Silva, J.A.; Esperança, J.M.S.S.; Araújo, J.M.M.; Rebelo, L.P.N.; Freire, M.G.; Pereiro, A.B. Fluorination effects on the thermodynamic, thermophysical and surface properties of ionic liquids. J. Chem. Thermodyn. 2016, 97, 354-361. [CrossRef]

58. Gaspar, M.M.; Calado, S.; Pereira, J.; Ferronha, H.; Correia, I.; Castro, H.; Tomás, A.M.; Cruz, M.E.M. Targeted delivery of paromomycin in murine infectious diseases through association to nano lipid systems. Nanomedicine 2015, 11, 1851-1860. [CrossRef]

59. Nave, M.; Castro, R.E.; Rodrigues, C.M.; Casini, A.; Soveral, G.; Gaspar, M.M. Nanoformulations of a potent copper-based aquaporin inhibitor with cytotoxic effect against cancer cells. Nanomedicine 2016, 11, 1817-1830. [CrossRef]

60. Messali, M.; Aouad, M.R.; El-Sayed, W.S.; Ali, A.A.; Hadda, T.B.; Hammouti, B. New Eco-Friendly 1-Alkyl-3-(4-phenoxybutyl) Imidazolium-Based Ionic Liquids Derivatives: A Green Ultrasound-Assisted Synthesis, Characterization, Antibacterial Activity and POM Analyses. Molecules 2014, 19, 11741-11759. [CrossRef]

61. Petkovic, M.; Ferguson, J.L.; Gunaratne, H.Q.N.; Ferreira, R.; Leitão, M.C.; Seddon, K.R.; Rebelo, L.P.N.; Pereira, C.S. Novel biocompatible cholinium-based ionic liquids-Toxicity and biodegradability. Green Chem. 2010, 12, 643-649. [CrossRef]

62. Khan, A.S.; Nasrullahc, A.; Ullah, Z.; Bhat, A.H.; Ghanem, O.B.; Muhammad, N.; Rashid, M.U.; Man, Z. Thermophysical properties and ecotoxicity of new nitrile functionalized protic ionic liquids. J. Mol. Liq. 2018, 249, 583-590. [CrossRef]

63. Silhavy, T.J.; Kahne, D.; Walker, S. The Bacterial Cell Envelope. Cold Spring Harb. Perspect. Biol. 2010, 2, a000414. [CrossRef]

64. Hoke, R.A.; Bouchelle, L.D.; Ferrell, B.D.; Buck, R.C. Comparative Acute Freshwater Hazard Assessment and Preliminary PNEC Development for Eight Fluorinated Acids. Chemosphere 2012, 87, 725-733. [CrossRef] [PubMed]

65. Gal, N.; Malferarri, D.; Kolusheva, S.; Galletti, P.; Tagliavini, E.; Jelinek, R. Membrane interactions of ionic liquids: Possible determinants for biological activity and toxicity. Biochim. Biophys. Acta Biomembr. 2012, 1818, 2967-2974. [CrossRef]

66. Kumar, R.A.; Papaiconomou, N.; Lee, J.; Salminen, J.; Clark, D.S.; Prausnitz, J.M. In vitro cytotoxicities of ionic liquids: Effect of cation rings, functional groups, and anions. Environ. Toxicol. 2008, 24, 388-395. [CrossRef]

67. Petkovic, M.; Seddon, K.R.; Rebelo, L.P.R.; Silva, C. Ionic liquids: A pathway to environmental acceptability. Chem. Soc. Rev. 2011, 40, 1383-1403. [CrossRef]

68. Ranke, J.; Molter, K.; Stock, F.; Bottin-Weber, U.; Poczobutt, J.; Hoffmann, J.; Ondruschka, B.; Filser, J.; Jastorff, B. Biological effects of imidazolium ionic liquids with varying chain lengths in acute vibrio fischeri and WST-1 cell viability assays. Ecotoxicol. Environ. Saf. 2004, 58, 396-404. [CrossRef] 